schools, for which the Foundation is sponsoring the preparation of teaching materials, as well as planning an enquiry into the content of the secondary school curriculum. It is also concerned with the proposal now under discussion to form an advisory body concerned with schools' curriculum and examinations, and would be providing professional assistance to the reconstituted Central Advisory Council in their study of primary education under the chairmanship of Lady Plowden.

\section{The Colonial Development Corporation}

The annual report of the Colonial Development Corporation for the year ended December 31, 1962, records 110 approved projects at the end of the year, of which eight, totalling an investment of $£ 1.63$ million, were new (Pp. vi +95. London: H.M.S.O., 1963. 6s. 6d. net). These were: in the Far East, the Sarawak Electricity Supply Corporation and Fiji Agricultural Trials; in East Africa, the Chinja and the Metaara Tea Supply Co., Ltd., the Mauritius Housing Corporation, and the Nairobi City Water Supply; and in the High Commission Territories, the Basutoland Electricity Authority and Vuvulane Irrigated Farms. Additional investment of $£ 1,882,000$ in existing projects has been approved. Of the committed capital at the end of the year, $£ 15.8$ million was in the Caribbean, $£ 20 \cdot 6$ million in the Far East, $£ 23.6$ million in East Africa, $£ 22.6$ million in Central Africa, $£ 21 \cdot 3$ million in the High Commission Territories, and $£ 13.3$ million in West Africa. Of this total, 53.7 per cent was for basic development, 34.5 per cent for primary production and processing, and 11.8 per cent for commerce and industry; for 1961 the corresponding figures are $54 \cdot 8$ per cent, 34.4 per cent and $10 \cdot 8$ per cent, respectively.

\section{The Macaulay Institute for Soil Research}

As has been the case with many research institutes, the Macaulay Institute for Soil Research was first accommodated in a country house at Craigiebuckler on the outskirts of Aberdeen. As its activities increased, temporary buildings were erected in the grounds and eventually a completely new building was planned and erected. This was formally opened in September 1962 by $\mathrm{Mr}$. D. L. Macaulay, a son of the founder, and is an excellent example of a modern research establishment, finished in a style compatible with the nature of the work being carried out. Every effort has been made to overcome troubles from chemical corrosion, noise and vibration, and air-conditioning is installed in certain sections.

The report for 1961-62 gives a brief description of the great variety of studies in progress ( $\mathrm{Pp} .55+1$ plate. Craigiebuckler, Aberdeen: The Macaulay Institute for Soil Research, 1963). It is sufficient to mention that there are departments of pedology, soil survey, spectrochemistry, biochemistry, plant physiology, microbiology, soil fertility and statistics. But the research programme involves considerable collaboration between departments. For example, investigations on crop performance embrace field, pot and laboratory studies, major and micronutrients and statistical evaluation of the results. A. few of the topics dealt with in recent publications concern principles of soil classification, direct-reading spectrochemical methods, natural chelating substances, cationexchange of plant tissues, phosphate-dissolving microorganisms, fractionation of organic phosphate, minerals in clays, weathering of basic igneous rock, the genetic soil groups of Scotland, response to fertilizers-all indicative of the rapid development of soil science in the past thirty years.

\section{Disarmament and Arms Control}

Disarmament and Arms Control, a new international quarterly journal, has been launched to provide a forum for the discussion of disarmament, arms control and related topics in the belief that well-informed discussion of such issues can reduce the present manifest dangers of mankind (1, No. 1 ; Summer 1963. Pp. v+1-110. Subscription rates: ' $A$ ', $£ 10$ ( 30 dollars) applicable to libraries, Government departments and industrial establishments; ' $B$ ', 22 (6 dollars) for individual subseribers, who certify to the publishers that the journal is for their personal use. London and New York: Pergamon Press, 1963). Its aim is to encourage the exchange of ideas and experience between workers in different countries, and it is hoped to include a regular section of comments by readers; the periodical is dedicated to the improvement of communication and understanding by seeking to formulate and clarify the new concepts required. For the present it is published in English only, with abstracts of each article in Russian, French and German, but a full translation of any article can be obtained on application to the publishers. The present issue is being distributed by the American Academy of Arts and Sciences to its Fellows and Foreign Members. The first number is admirably printed and produced and its quality is illustrated sufficiently by the titles and authors of its five main articles: "First Step-Sealed Records Caches ?", by J. C. Polanyi; "The Role of the Neutrals in the Geneva Negotiations", by M. Samir Ahmed; "Violations of Disarmament Agreements", by R. J. Barnet; "The International Control of Fissile Material Production"-being a shortened version of a paper contributed by the Atomic Energy Authority to the Disarmament Conference at Geneva in August 1962; "A Proposal for an African and Near-Eastern Zone Free from Certain Weapons", by D. H. Frisch. Besides book reviews, there is a section containing short abstracts of current literature and research. The first issue seems well designed for its purpose and should strengthen the efforts in this field which scientists are already making through the Pugwash movement and in other ways.

\section{Atom}

The June 1963 issue of Atom completes W. F. Wood's review of the reactors at Harwell commenced in the May issue. In the July issue is printed a lecture by $\mathbf{J}$. F. Putman on economic aspects of the technical application of radioisotopes, which gives some impressive savings. Annual savings in the United Kingdom through the use of radioisotopes are estimated at $£ 3.5$ million, but potential savings at $£ 14.5$ million, including $£ 2.75$ million in the paper and board industries, $£ 1.9$ million in chemical industry, $£ 1.05$ million in iron and ste日l, and $£ 1.775$ million in electrical engineering. The number of British firms using radioisotopes has increased from 658 in 1957 to about 1,200 .

\section{Apartheid and the South African Library Association}

THE Library Association Record for June 1963 includes a note from more than thirty members of the staff of the Johannesburg Public Library giving the text of a resolution passed at a general meeting of the Southern Transvaal Branch of the South African Library Association deploring the decision taken by the South African Library Association Conference in resolving to enforce separate racial associations on the library profession (see Nature, 196, $1242 ; 1962)$. The resolution sets forth reasoned objections. It maintains that common professional ideals, aims, interests and problems form a bond which transcends differences of age, sex, religion, politics, language, race or colour, and therefore strongly objects to any of these fortuitous differences being utilized to build artificial barriers between colleagues. The Association is numerically small and fragmentation can only weaken the Association and produce separate and even impractically tiny bodies. Since the Government intends to enforce apartheid on profesional associations, it is urged that the action of the Conference was untimely and unnecessary. 